\title{
Nitrogen, carbon, and sulfur isotopic change during heterotrophic (Pseudomonas aerofaciens) and autotrophic (Thiobacillus denitrificans) denitrification reactions
}

\author{
Takahiro Hosono $^{a^{*}}$, Kelly Alvarez ${ }^{\mathrm{a}}$, In-Tian Lin ${ }^{\mathrm{b}}$, Jun Shimada ${ }^{\mathrm{b}}$ \\ a Priority Organization for Innovation and Excellence, Kumamoto University, 2-39-1 \\ Kurokami, Kumamoto 860-8555, Japan. \\ ${ }^{\mathrm{b}}$ Graduate School of Science and Technology, Kumamoto University, 2-39-1, Kurokami, \\ Kumamoto 860-8555, Japan.
}

${ }^{*}$ Corresponding author.

Tel \& Fax: +81-96-342-3935 Email address: hosono@kumamoto-u.ac.jp (T. Hosono)

\begin{abstract}
In batch culture experiments, we examined the isotopic change of nitrogen in nitrate $\left(\delta^{15} \mathrm{~N}_{\mathrm{NO} 3}\right)$, carbon in dissolved inorganic carbon $\left(\delta^{13} \mathrm{C}_{\mathrm{DIC}}\right)$, and sulfur in sulfate $\left(\delta^{34} \mathrm{~S}_{\mathrm{SO} 4}\right)$ during heterotrophic and autotrophic denitrification of two bacterial strains (Pseudomonas aerofaciens and Thiobacillus denitrificans). Heterotrophic denitrification (HD) experiments were conducted with trisodium citrate as electron donor, and autotrophic denitrification (AD) experiments were carried out with iron disulphide $\left(\mathrm{FeS}_{2}\right)$ as electron donor. For heterotrophic denitrification experiments, a complete nitrate reduction was accomplished, however bacterial denitrification with $T$. denitrificans is a slow process in which, after seventy days nitrate was reduced to $40 \%$ of the initial concentration by denitrification. In the HD experiment, systematic change of $\delta^{13} \mathrm{C}_{\mathrm{DIC}}$ (from $-7.7 \%$ to $-12.2 \%$ ) with increase of DIC was observed during denitrification (enrichment factor $\varepsilon \mathrm{N}$ was $-4.7 \%$ ), suggesting the contribution of $\mathrm{C}$ of trisodium citrate $\left(\delta^{13} \mathrm{C}=-12.4 \%\right)$. No $\mathrm{SO}_{4}{ }^{2-}$ and $\delta^{34} \mathrm{~S}_{\mathrm{SO} 4}$ changes were observed. In the $\mathrm{AD}$ experiment, clear fractionation of $\delta^{13} \mathrm{C}_{\mathrm{DIC}}$ during DIC consumption $(\varepsilon \mathrm{C}=-7.8 \%$ ) and $\delta^{34} \mathrm{~S}_{\mathrm{SO} 4}$ during sulfur use of $\mathrm{FeS}_{2}-\mathrm{S}$ (around 2\%), were confirmed through denitrification ( $\varepsilon \mathrm{N}=-12.5 \%$ ). Different pattern in isotopic change between HD and AD obtained on laboratory-scale are useful to recognize the type of denitrification occurring in the field.
\end{abstract}

Keywords: heterotrophic denitrification; autotrophic denitrification; isotope fractionation; $\mathrm{C}, \mathrm{N}, \mathrm{S}$ isotopes; batch culture experiments 


\section{Introduction}

Controlling and reducing the nitrate content in aquifers is critical for the quality of water systems. Among nitrate biological removal methods, heterotrophic and autotrophic denitrifying microorganisms are important mediators in the denitrification process of nitrate-contaminated ground and surface waters. Biological denitrification including both heterotrophic denitrification (HD) and autotrophic denitrification (AD), is the anaerobic process which allows the breakdown of nitrates by bacteria, resulting in the release of gaseous products $\mathrm{N}_{2} \mathrm{O}$ and $\mathrm{N}_{2}$ into atmosphere (Korom, 1992).

HD process requires an organic carbon source, which can be supplied as soluble (glucose, citrate, methanol, ethanol, etc.) (e.g., Akunna et al., 1993; Christensson et al., 1994; Nyberg et al., 1996; Soares, 2000) or insoluble carbon compounds (cellulose based materials such as newspaper, wheat straw, cotton, etc.) (e.g., Volokita et al., 1996a; Volokita et al., 1996b; Schipper et al., 2004; Aslan and Turkman, 2005). In the case of trisodium citrate as a sole carbon source, the denitrifying reaction may be simplified as:

$$
\mathrm{Na}_{3} \mathrm{C}_{6} \mathrm{H}_{5} \mathrm{O}_{7(\mathrm{~s})}+3 \mathrm{NO}_{3}^{-}{ }_{(\mathrm{aq})}^{-} \rightarrow 3 / 2 \mathrm{~N}_{2(\mathrm{~g})}+3 \mathrm{NaHCO}_{3(\mathrm{~s})}+3 \mathrm{CO}_{2(\mathrm{~g})}+\mathrm{H}_{2} \mathrm{O}
$$

On the other hand, $\mathrm{AD}$ can be carried out using zero-valent iron (e.g., Choe et al., 2004; Biswas and Bose, 2005), ferrous ions (e.g., Benz et al., 1998), elemental sulphur (e.g., Batchelor and Lawwrence, 1986; Soares, 2002; Mohammadi et al., 2011) or reduced sulfur compounds such as $\mathrm{FeS}_{2}$ (pyrite) (e.g., Haaijer et al., 2007; Jorgensen et al., 2009; Torrentó et al., 2010), typically supplied as granular material, as an electron donor and reduces nitrate or nitrite to nitrogen gas. Pyrite is the stable iron sulfide phase in anoxic low-temperature sedimentary or aquatic environments (Rickard and Luther, 2007) and has been proposed as an abundant and inexpensive material, which can be easily decomposed by bacteria action especially when the pyrite is provided in fine crystals and dust (Rickard and Luther, 2007). For the $\mathrm{FeS}_{2}$ case the following denitrification overall reaction is expected (Torrentó et al., 2010):

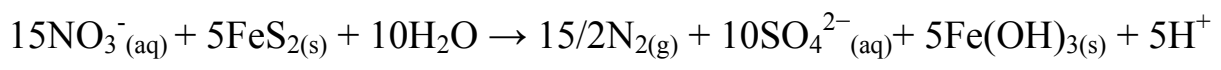

The coupled $\mathrm{N}$ and $\mathrm{O}$ isotope behavior during in $\mathrm{HD}$ and $\mathrm{AD}$ reactions has been studied in laboratory-scale using pure cultures of heterotrophic and autotrophic bacteria 
and is very well acknowledged (e.g., Wellman et al., 1968; Delwiche and Steyn, 1970; Barford et al., 1999; Granger et al., 2008; Knöeller et al., 2011; Wunderlich et al., 2012; Torrentó et al., 2010). In both cases, HD and AD, a decrease in nitrate concentration is coupled with an increase in the $\delta^{15} \mathrm{~N}$ and $\delta^{18} \mathrm{O}$ of residual nitrate and it has been commonly thought that the fractionation ratio of $\delta^{15} \mathrm{~N}_{\mathrm{NO} 3}$ and $\delta^{18} \mathrm{O}_{\mathrm{NO} 3}$ during denitrification ranges within 1.3-2.1 (Aravena and Robertson, 1998; Mengis et al., 1999; Böttcher et al., 1990; Fukada et al., 2003).

Carbon dioxide is one of the by-products of HD reaction (Eq. (1)). Since the organic source carbon is isotopically more depleted in ${ }^{13} \mathrm{C}$ compared to that of the carbonate/bicarbonate pools (i.e., alkalinity) (Nascimento et al., 1997), the $\delta^{13} \mathrm{C}$ values of the DIC containing this carbon will be more negative than the DIC which either does not contain this carbon or the DIC whose $\delta^{13} \mathrm{C}$ has been modified significantly by carbonate dissolution (Schulte et al., 2011). Therefore, the carbon isotope ratios of DIC can serve as a useful tool in monitoring HD.

Similarly, sulfate is one of the productions of AD reaction through pyrite oxidation (Eq. (2)). During sulfide oxidation a moderate isotopic fractionation, ranging from $-4 \%$ to 3.5\% , was reported between sulfide metals and dissolved sulfate (Balci et al., 2007, 2012; Pisapia et al., 2007; Thurston et al., 2010; Heidel and Tichomirowa, 2011; Brabec et al., 2012; Heidel et al., 2013). Since sulfur in sulfide minerals is typically more depleted in $\delta^{34} \mathrm{~S}$ compared to that of sulfate pools in earth surface environments (i.e., evaporate) (Krouse and Grinenko, 1991; Bottrell and Newton, 2006), a depression of $\delta^{34} \mathrm{~S}$ values of sulfur in produced sulfate might be expected with the progress of AD reaction.

A coupled use of chemical data with the $\delta^{15} \mathrm{~N}$ and $\delta^{18} \mathrm{O}$ of dissolved nitrate and the isotopic compositions of the ions involved in denitrification reactions, as, for example, the $\delta^{34} \mathrm{~S}$ of dissolved sulfate, and/or the $\delta^{13} \mathrm{C}$ of dissolved inorganic carbon, can be applied to determine the relative role of heterotrophic and autotrophic processes in natural denitrification. In fact, the use of combined $\delta^{15} \mathrm{~N}_{\mathrm{NO} 3}, \delta^{13} \mathrm{C}_{\mathrm{DIC}}$, and $\delta^{34} \mathrm{~S}_{\mathrm{SO} 4}$ for natural aquifer systems have been proposed to distinguish the kind of denitrification occurring in aquifer (Aravena and Robertson, 1998; Otero et al., 2009; Carrey et al., 2013; Puig et al., 2013; Hosono et al., 2014). For instance, in a field study in a shallow aquifer Aravena and Robertson (1998) found that as denitrification proceeds $\delta^{15} \mathrm{~N}_{\mathrm{NO}}$ showed a drastic increasement $\left(6.4 \%\right.$ to $58.3 \%$ ) and at the same time $\delta^{13} \mathrm{C}_{\mathrm{DIC}}$ values decreased $(-1.9 \%$ to $-8.6 \%$ ). In this study, the authors suggested that this decline in $\delta^{13} \mathrm{C}_{\mathrm{DIC}}$ could be regarded as an indicator of heterotrophic denitrification. Otero et al. (2009) found also a distinct trend in $\delta^{34} \mathrm{~S}_{\mathrm{SO} 4}$ as denitrification occurred in a deep aquifer 
in Spain. In this case of study $\delta^{34} \mathrm{~S}_{\mathrm{SO} 4}$ decreased (10\% to $-20 \%$ ) while an enrichment of $\delta^{15} \mathrm{~N}_{\mathrm{NO} 3}$ (10\% to $35 \%$ ) was observed. The authors suggested that this declining in $\delta^{34} \mathrm{~S}_{\mathrm{SO} 4}$ is an indication that the denitrification here proceeded autotrophically. However, the behavior of $\delta^{13} \mathrm{C}_{\mathrm{DIC}}$ and $\delta^{34} \mathrm{~S}_{\mathrm{SO} 4}$ during $\mathrm{HD}$ and $\mathrm{AD}$ has rarely been reported in batch experiments and the utility of this multi-isotopic approach has not been fully evaluated and evidenced at laboratory scale yet.

The purpose of this study was to find out the extent to which $\delta^{15} \mathrm{~N}_{\mathrm{NO} 3}, \delta^{13} \mathrm{C}_{\text {DIC }}$, and $\delta^{34} \mathrm{~S}_{\mathrm{SO} 4}$ isotopes are discriminated during HD and $\mathrm{AD}$ in anaerobic microbial cultures. In this study, we used two pure denitrifier cultures: Pseudomonas aerofaciens and Thiobacillus denitrificans capable of heterotrophic and autotrophic denitrification, respectively. In order to evaluate the isotopic response in HD and AD processes two different experiments were carried out: (1) 120 hours batch experiment with $P$. aerofaciens reacting with a trisodium citrate medium with a defined amount of $\mathrm{NO}_{3}{ }^{-}$and (2) 70 days batch experiment of $\mathrm{T}$. denitrificans reacting with pyrite and a $\mathrm{SO}_{4}{ }^{2-}$ free medium. The obtained data allow evaluating the magnitude of the isotopic fractionation expected in nitrate-contaminated water systems.

\section{Materials and methods}

\subsection{Pyrite preparation}

Cuboid pyrite crystals of more than $99 \%$ of purity were obtained from sedimentary deposits in Navajún, La Rioja (Spain). The minor impurities are Ni and Co. These impurities do not affect the basic cubic structure. To generate a clean pyrite surface, the experimental procedure suggested by Sasaki et al. (1995) was followed. This procedure would create a condition that the chemical species on the surface of the pyrite are only iron (Fe) and sulfur (S) (Sasaki et al., 1995). Briefly, the crystals were pulverized in a tungsten carbide vessel using a Herzog HSM-F36 (Germany) in order to obtain a particle size of approximately $5 \mu \mathrm{m}$. The pyrite powder was washed in Milli-Q pure water and ultrasonicated for $1 \mathrm{~h}$ to remove fine pyrite particles adhering to the surface. Subsequently, it was shaken in a $10 \%$ hydrochloric acid solution at $90 \mathrm{rpm}$ for 1 hour to remove possible impurities on the pyrite surface. At this point, the powder was rinsed with Milli-Q pure water and ultrasonicated three times to eliminate the acid from the surface. Then, the pyrite powder was sterilized and dehydrated with pure ethanol and finally was vacuum-dried in an oven (EYELA VOS-301SD, Tokyo Rikakikai Co. Ltd, Japan) at $60^{\circ} \mathrm{C}$ for 1 day. The final material was stored in a $\mathrm{N}_{2}$-purged desiccator for 
batch culture experiments.

\subsection{Growth and maintenance of bacterial cultures}

For the heterotrophic denitrification experiments, cells of $P$. aerofaciens (strain ATCC No. 13985) were obtained from the German Collection of Microorganisms and Cell Culture (GCMCC) and were grown under sterile conditions in a citrate minimal medium (CMM) used previously by Anderson et al. (1993), containing $53.3 \mathrm{mM}$ of $\mathrm{K}_{2} \mathrm{HPO}_{4}$ and $13.3 \mathrm{mM}$ of $\mathrm{KH}_{2} \mathrm{PO}_{4}$ in 1 liter of distilled water adjusted to $\mathrm{pH} 7.5$ and autoclaved prior to addition of the following filter-sterilized (pore size, $0.2 \mu \mathrm{m}$ ) reagents: $4.24 \mathrm{mM}$ of $\left(\mathrm{NH}_{4}\right)_{2} \mathrm{SO}_{4}, 0.1 \mathrm{mM}$ of $\mathrm{Na}_{2} \mathrm{MoO}_{4} \cdot 2 \mathrm{H}_{2} \mathrm{O}, 0.02 \mathrm{mM}$ of $\mathrm{FeSO}_{4} \cdot 7 \mathrm{H}_{2} \mathrm{O}, 0.005$ $\mathrm{mM}$ of $\mathrm{MnCl}_{2} \cdot 4 \mathrm{H}_{2} \mathrm{O}, 0.35 \mathrm{mM}$ of $\mathrm{CaCl}_{2} \cdot 2 \mathrm{H}_{2} \mathrm{O}, 0.81 \mathrm{mM}$ of $\mathrm{MgSO}_{4} \cdot 7 \mathrm{H}_{2} \mathrm{O}$, and $4.6 \mathrm{mM}$ of trisodium citrate $\left(\mathrm{Na}_{3} \mathrm{C}_{6} \mathrm{H}_{5} \mathrm{O}_{7}\right)$. Exponentially growing $P$. aerofaciens preparations were produced by growing cultures in $\mathrm{CMM}$ for two days at $25^{\circ} \mathrm{C}$ and unshaken. $T$. denitrificans (strain ATCC No. 23644) a classic autotrophic denitrifying bacteria was

purchased from GCMCC. Cells of T. denitrificans were grown in batch culture in a synthetic medium $(100 \mathrm{ml})$ containing the following reagents: $\mathrm{Na}_{2} \mathrm{HPO}_{4}(3.35 \mathrm{mM})$, $\mathrm{KH}_{2} \mathrm{PO}_{4}(13.24 \mathrm{mM}), \mathrm{MgSO}_{4} \cdot 7 \mathrm{H}_{2} \mathrm{O}(0.41 \mathrm{mM}),\left(\mathrm{NH}_{4}\right)_{2} \mathrm{SO}_{4}(0.76 \mathrm{mM}), \mathrm{CaCl}_{2} \cdot 2 \mathrm{H}_{2} \mathrm{O}$ (0.20 mM), $\mathrm{FeCl}_{3} \cdot 6 \mathrm{H}_{2} \mathrm{O}(0.074 \mathrm{mM}), \mathrm{MnSO}_{4} \cdot \mathrm{H}_{2} \mathrm{O}(0.12 \mathrm{mM}), \mathrm{Na}_{2} \mathrm{~S}_{2} \mathrm{O}_{3} \cdot 5 \mathrm{H}_{2} \mathrm{O}$ (40.32 $\mathrm{mM}), \mathrm{NaHCO}_{3}(5.95 \mathrm{mM})$, and $\mathrm{KNO}_{3}(5 \mathrm{mM})$. All chemicals were of analytical grade. T. denitrificans cultures were incubated for two weeks, maintained under anaerobic conditions at $25^{\circ} \mathrm{C}$ and unshaken.

\subsection{Experimental setting for $H D$}

After cultures were grown in CMM medium to late exponential growth phase, 150 $\mathrm{ml}$ cultures were combined and concentrated by centrifugation at $3287 \times \mathrm{g}$ for $10 \mathrm{~min}$ at $0^{\circ} \mathrm{C}$. The supernatant was discarded and the cell pellets were resuspended in $60 \mathrm{ml}$ $\mathrm{CMM}$ medium with $\mathrm{KNO}_{3}$ (sole nitrate source) to a final concentration of $10 \mathrm{mM} \mathrm{NO}_{3}^{-}$. Batch cultures experiments were started by diluting in anaerobic conditions $3 \mathrm{~mL}$ of resuspended culture into $100 \mathrm{~mL}$ of fresh $\mathrm{CMM}$ medium with $10 \mathrm{mM} \mathrm{NO}_{3}{ }^{-}$in a $100 \mathrm{ml}$ bottle purged with $\mathrm{N}_{2}$ for 1 hour. In total, 19 bottles of $100 \mathrm{ml}$ containing bacterial cells and CMM medium with $10 \mathrm{mM} \mathrm{NO}_{3}{ }^{-}$were incubated static for 120 hours inside a nitrogen gas glove box at $25^{\circ} \mathrm{C}$. As a blank (regarded as starting composition at time 0 ) 1 bottle containing $\mathrm{CMM}$ medium with $10 \mathrm{mM} \mathrm{NO}_{3}{ }^{-}$only was stored for the same period of time as an uninoculated control under the same conditions. The biological 
reaction was stopped by the addition of $2 \mathrm{ml}$ of $10 \mathrm{~N} \mathrm{NaOH}$ every 4 hours. This period was chosen after pilot experiments done and taking into account the growth rate of $P$. aerofaciens. At the end of the experiment, the water samples in the bottles were filtered $(0.2 \mu \mathrm{m})$ and $20 \mathrm{ml}$ aliquots were taken for carbon and nitrate isotope measurements, this water samples were kept tightly sealed and frozen until the concentration and $\mathrm{C}$ and $\mathrm{N}$ isotope measurements were done. For $\delta^{34} \mathrm{~S}$ isotope analysis the remaining of the filtrate of each bottle was preserved acidified to $\mathrm{pH}<2$ with $20 \% \mathrm{HCl}$ solution in order to remove $\mathrm{HCO}_{3}{ }^{-}$and $\mathrm{CO}_{3}{ }^{2-}$ species. Water soluble sulfate was precipitated as barite $\left(\mathrm{BaSO}_{4}\right)$ by adding a solution of $\mathrm{BaCl}_{2}$. The precipitates were filtered with a $0.45 \mu \mathrm{m}$ pore size filter, were rinsed with deionized water twice and finally oven-dried at $100^{\circ} \mathrm{C}$ for 3 hours.

\subsection{Experimental setting for $A D$}

After cultures were grown for two weeks to late exponential phase, $600 \mathrm{ml}$ cultures were combined and concentrated by centrifugation at $3287 \times g$ for $10 \mathrm{~min}$ at $0^{\circ} \mathrm{C}$. The supernatant was discarded and the cell pellets were resuspended in $150 \mathrm{ml}$ of modified synthetic medium without $\mathrm{SO}_{4}{ }^{2-}$ (modified synthetic medium: $\mathrm{NH}_{4} \mathrm{Cl}(18.7 \mathrm{mM}$ ), $\mathrm{KH}_{2} \mathrm{PO}_{4}(14.7 \mathrm{mM}), \mathrm{NaHCO}_{3}(30 \mathrm{mM}), \mathrm{MgCl}_{2} \cdot 6 \mathrm{H}_{2} \mathrm{O}(3.25 \mathrm{mM}), \mathrm{CaCl}_{2} \cdot 2 \mathrm{H}_{2} \mathrm{O}(0.05$ $\left.\mathrm{mM}), \mathrm{KNO}_{3}(5 \mathrm{mM})\right)$ to minimize the sulfate blank. The $\mathrm{pH}$ of the final modified synthetic medium was adjusted to 7.2 with a $\mathrm{K}_{2} \mathrm{HPO}_{4}-\mathrm{KH}_{2} \mathrm{PO}_{4}$ buffer. The autoclaved modified medium solution was purged with $\mathrm{N}_{2}$ for 1 hour before inoculation with bacteria to remove the dissolved oxygen. The bottles of the modified medium containing the pyrite powder were equilibrated inside the anaerobic chamber for 2 days prior to the start of the experiments. The experimental cultures were prepared by inoculating, in anaerobic conditions, $5 \mathrm{ml}$ of resuspended cultures into $200 \mathrm{ml}$ of the modified synthetic medium containing $4 \mathrm{~g}$ of pyrite powder, in a $250 \mathrm{ml}$ pre-sterilized polyethylene bottle. The $5 \mathrm{ml}$ cell suspensions were added to each bottle before the bottles were sealed with a gas headspace inside the anaerobic chamber. Under these conditions pyrite will be the only electron donor available for the cultured cells. The $250 \mathrm{ml}$ bottles containing modified medium, pyrite and bacterial cells were incubated for 70 days. This period was chosen after pilot experiments done and taking into account the growth rate of $T$. denitrificans. For each sampling time point the $\mathrm{pH}$ of the solutions was measured, the liquid in the bottle was filtered $(0.2 \mu \mathrm{m})$ to separate the pyrite from the modified medium containing the cells and the possible bacterial activity in the filtrate was stopped by the injection of $5 \mathrm{ml}$ of $10 \mathrm{~N} \mathrm{NaOH}$. At the beginning of 
the experiment, this process was performed every day. After the day sixteen the interval of time to stop the reaction was changed from 1 to every 3 days since the $\mathrm{NO}_{3}$ concentration of the samples didn't change very much, and for the last three intervals of time the reaction was stopped after 7 days. In total, 30 bottles for each time-point containing modified medium + pyrite + bacterial cells and 1 blank consisting of medium and pyrite only (no cells, regarded as starting composition at time 0 ) were produced. The 31 bottles were stored static the seventy days inside a nitrogen gas glove box. Table 1 summarizes the conditions varied for denitrifiers in the HD and AD denitrification experiments. Since $T$. denitrificans activity is very $\mathrm{pH}$ sensitive, at each sampling time point it was confirmed that the $\mathrm{pH}$ values of the liquid inside the bottles was between 7 and 8 throughout the incubations.

\subsection{Chemical and isotope analyses}

Samples were analyzed for chemical and isotopic composition, nitrate concentration varied during denitrification; after nitrate concentration became constant the samples were not analyzed for isotope ratios.

\subsubsection{Concentrations of $\mathrm{SO}_{4}{ }^{2-}$ and $\mathrm{NO}_{3}{ }^{-}$}

The content of $\left[\mathrm{SO}_{4}{ }^{2-}\right]$ and $\left[\mathrm{NO}_{3}{ }^{-}\right]$fractions of samples solutions were determined by ion chromatography (IC) using a 761 Compact IC System, equipped with an anion-separator column (Dual 2) and a conductivity detector (Metrohm, Switzerland). For the heterotrophic and autotrophic cultures the samples for IC were collected by taken an aliquot of $1 \mathrm{ml}$ of the supernatant from each of the bottles and were diluted by a factor of 100 with de-ionized water. Diluted samples were measured after filtration through a $0.2 \mu \mathrm{m}$ syringe filter.

\subsubsection{Isotope ratios of nitrate and oxygen in $\mathrm{NO}_{3}{ }^{-}$}

The $\delta^{15} \mathrm{~N}_{\mathrm{NO} 3}$ and $\delta^{18} \mathrm{O}_{\mathrm{NO} 3}$ were analyzed using an isotopic ratio mass spectrometer (IRMS) (Finnigan Delta V Advantage, Thermo Fisher Scientific, USA), coupled with a headspace gas sampler (GasBench II, Thermo Fisher Scientific, USA). The samples preparation follows the bacterial denitrifier method developed by Sigman et al. (2001) and Casciotti et al. (2002), which is outlined briefly here. Pseudomonas aerofaciens ( $P$. aerofaciens) cultures grown for 3 days are concentrated 5-fold by centrifugation and then split into $4.5 \mathrm{ml}$ aliquots in $20 \mathrm{ml}$ glass vials. The vials are crimp-sealed with Teflon-backed silicone septa and purged for $2 \mathrm{~h}$ with high purity $(99.9995 \%) \mathrm{N}_{2}$ gas. 
The $\mathrm{NO}_{3}$ concentration of the samples for nitrate isotope analysis is calculated using ion chromatography, so the dissolved nitrate is then added to the sample glass vials and is incubated for 12 hours to allow the complete conversion of nitrate to $\mathrm{N}_{2} \mathrm{O}$ before the addition of $0.1 \mathrm{ml}$ of $10 \mathrm{~N} \mathrm{NaOH}$ to stop bacterial activity. Nitrogen and oxygen isotope ratios were measured relative to Air- $\mathrm{N}_{2}$ and VSMOW, respectively. For calibration of nitrogen and oxygen isotope values of the samples the reference nitrates IAEA-N3, USGS 34 and USGS 35 were used. Standards were reacted and analyzed in parallel to samples, with an aliquot of each standard analyzed initially and after every five experimental samples. Based on replicate measurements of standards and samples $(n=$ 40 ), the analytical precisions for $\delta^{15} \mathrm{~N}_{\mathrm{NO} 3}$ and $\delta^{18} \mathrm{O}_{\mathrm{NO} 3}$ were better than $\pm 0.2 \%$ and $\pm 0.3 \%$ o, respectively, during the analytical period.

\subsubsection{Carbon isotope ratio and concentration of DIC}

Water samples were analyzed for carbon isotope and concentration of DIC using a headspace gas sampler (GasBench II, Thermo Fisher Scientific, USA) coupled to an IRMS (Finnigan Delta V Advantage; Thermo Fisher Scientific, USA). In brief, $1 \mathrm{ml}$ of liquid sample was taken and treated with $100 \% \mathrm{H}_{3} \mathrm{PO}_{4}$ previously flushed with high purity $(99.9996 \%) \mathrm{He}$ in a glass vial at $25^{\circ} \mathrm{C}$. The $\mathrm{CO}_{2}$ produced in the headspace of the vial is transferred into the mass spectrometer and $\delta^{13} \mathrm{C}$ values were measured. Reproducibility of $\delta^{13} \mathrm{C}$ values is reported in per mil relative to Vienna Peedee Belemnite (VPDB). Final $\delta^{13} \mathrm{C}$ values are obtained after adjusting the provisional values such that correct $\delta^{13} \mathrm{C}$ values for IAEA-CO-9 standard and laboratory standards. Based on replicate measurements of standards and samples $(n=41)$, the analytical precision of $\delta^{13} \mathrm{C}$ values was better than $\pm 0.1 \%$. For DIC concentration four laboratory standards of $\mathrm{CaCO}_{3}$ at four DIC concentrations $(2,3,4,5 \mathrm{mM})$ were prepared as calibration standards and were analyzed with every 5 samples. The $\mathrm{CaCO}_{3}$ powder was flushed with high purity helium gas for 2 hours and treated with an excess of $100 \% \mathrm{H}_{3} \mathrm{PO}_{4}$. The carbon isotope ratio of powdered $\mathrm{Na}_{3} \mathrm{C}_{6} \mathrm{H}_{5} \mathrm{O}_{7}$ was determined by mass spectrometry interfaced with an elemental analyzer (Flash 2000, Thermo Fisher Scientific, USA) (Table 2). The isotope values were calibrated using the IAEA-CO-9 and several interlaboratory standards. Analytical precision of the analysis is generally better than $\pm 0.15 \%$.

\subsubsection{Sulfur isotope ratio}

Water samples were filtered through $0.2 \mu \mathrm{m}$ cellulose acetate filters. Filtered samples were acidified to $\mathrm{pH} 2$ with distilled $6 \mathrm{M} \mathrm{HCl}$. The $\mathrm{SO}_{4}{ }^{2-}$ in acidified samples 
was collected as $\mathrm{BaSO}_{4}$ compounds by adding $10 \% \mathrm{BaCl}_{2}$ (aq). Afterwards, the samples were dried at $60{ }^{\circ} \mathrm{C}$ for $72 \mathrm{~h}$. Samples were combusted with $\mathrm{O}_{2}$ and $\mathrm{V}_{2} \mathrm{O}_{5}$ at $1030{ }^{\circ} \mathrm{C}$ using an elemental analyzer (Flash 2000, Thermo Fisher Scientific, USA) coupled to IRMS (Finnigan Delta V Advantage; Thermo Fisher Scientific, USA). Isotopic results are expressed in per mil basis (\%o) with respect to the Vienna Canyon Diablo Troilite (VCDT) standard. International reference materials IAEA-S2 and NBS 127 and some laboratory standards were used for calibration and quality check. The analytical precision for $\delta^{34} \mathrm{~S}_{\mathrm{SO} 4}$ was better than $\pm 0.2 \%$ o $(\mathrm{n}=35)$. The sulfur isotope ratio of powdered samples of $\mathrm{FeS}_{2}$ was also determined by IRMS interfaced with the same elemental analyzer (Table 2). Analytical precision of the analysis was better than $\pm 0.2 \%$.

\subsection{Enrichment factors}

In addition to the isotope changes as an indicator of denitrification, empirical isotope enrichment factors $\varepsilon$ can be calculated using differences in the isotopic composition and concentration of nitrate of samples. According to Mariotti et al. (1981) a simplified linearization of the Rayleigh model was used, in which the exponential decrease in nitrate concentration with isotopic enrichment produced by denitrification defines the isotopic enrichment factor $(\varepsilon)$. Using the linearized form of the Rayleigh equation (Eq. (3)), the slope of the line calculated from a linear regression analysis, approximates to the nitrogen isotopic enrichment factor $(\varepsilon N)$ (Mariotti et al., 1981):

$\delta^{15} \mathrm{~N}=\delta^{15} \mathrm{~N}_{\text {initial }}+\varepsilon \mathrm{N}\left(\ln \left[\mathrm{NO}_{3}^{-}\right]\right)$

Here, $\delta^{15} \mathrm{~N}$ and $\delta^{15} \mathrm{~N}_{\text {initial }}$ are the isotopic signatures of residual and initial nitrate, respectively, and $\left[\mathrm{NO}_{3}^{-}\right]$represent the concentration of the residual nitrate.

Similarly, equations of Rayleigh model for $\delta^{18} \mathrm{O}$ and $\delta^{13} \mathrm{C}$ can be defined as follows:

$$
\begin{aligned}
& \delta^{18} \mathrm{O}=\delta^{18} \mathrm{O}_{\text {initial }}+\varepsilon \mathrm{O}\left(\ln \left[\mathrm{NO}_{3}^{-}\right]\right) \\
& \delta^{13} \mathrm{C}=\delta^{13} \mathrm{C}_{\text {initial }}+\varepsilon \mathrm{C}\left(\ln \left[\mathrm{HCO}_{3}{ }^{-}\right]\right)
\end{aligned}
$$

The use of this Rayleigh model-based approach for the quantification of biodegradation, requires the existence of a constant isotopic fraction factor, and depends on the nature of the transport processes taking place during denitrification (Thullner et 
al., 2008). In our experiments, systematic degradation of $\mathrm{NO}_{3}$ by the previously mentioned anaerobic microorganisms was observed, and for simplicity, and to have a rough estimate of the enrichments factors the Rayleigh model was employed. However, microscale transport processes around the microbial cells may occur even in closed batch systems (Thullner et al., 2008), such as the diffusion of the substrate toward a bacterial cell (Harms, 1996) and adsorption across a cell membrane (Buttom, 1991; Buttom, 1998). Moreover, isotopic effects can be additionally influenced by other physical processes, e.g., an inhomogeneous substrate dispersion, not perfect anaerobic environment (or variations with time of other environmental conditions), and spatial and temporal heterogeneity of reaction rates (Well et al., 2012, Lewicka-Szczebak et al., 2014), which can occur, for example, due to the continuous bacterial growth during denitrification. Nevertheless, according to Meckenstock et al. (2004), values for enrichment factors determined using the Rayleigh approach provide a conservative estimate of biodegradation occurring in laboratory scale experiments.

\section{Results and discussion}

\subsection{Factors controlling composition and isotopic changes}

It is of considerable interest to determine the concentration and $\delta^{15} \mathrm{~N}, \delta^{13} \mathrm{C}$, and $\delta^{34} \mathrm{~S}$ characteristics changes with progress of $\mathrm{HD}$ and $\mathrm{AD}$ reaction, respectively. Denitrification by oxidation of organic matter (HD) should result in a decrease of nitrate concentration together with an increase in $\mathrm{HCO}_{3}{ }^{-}$concentration in near neutral $\mathrm{pH}$ condition. Fig. 1a shows the nitrate concentration variation with time. Concentrations of nitrate decreased systematically and nearly complete reduction of nitrate was obtained after approximately 50 hours, the rapid consumption of the electron acceptor species corresponds to a fast increase of the bacteria population. After that, the nitrates are completely consumed and the number of bacteria is stationary in time (Fig. 1a). Finally, a plateau region that was clearly observed at the end of the experiment indicating that the system reached a steady state (Fig. 1a). Accordingly, bicarbonate concentration tended to increase with time as nitrate is being consumed (Fig. 1b). It was observed that nitrate depletion and bicarbonate production occurred in a 1:1 proportion, as can be seen in Figs. 1a,b. Since Pseudomonas aerofaciens is an incomplete denitrifier strain that reduce $\mathrm{NO}_{3}{ }^{-}$to nitrous oxide $\left(\mathrm{N}_{2} \mathrm{O}\right)$, we propose the following corrected version of equation (1): 
In our case, we used as a carbon source $\mathrm{Na}_{3} \mathrm{C}_{6} \mathrm{H}_{5} \mathrm{O}_{7(\mathrm{~s})}$ and we suggest that carbon will accumulate into the biomass at the end of the reaction forming a biosolid. As shown in Fig. 1c sulfate concentration remained constant with time, as sulfate does not interfere in the HD reaction.

In general, nitrate elimination by denitrification produces an increase in $\delta^{15} \mathrm{~N}_{\mathrm{NO}}$ and $\delta^{18} \mathrm{O}_{\mathrm{NO} 3}$. Several field studies (e.g., Aravena and Robertson, 1998; Mengis et al., 1999; Fukada et al., 2003) and laboratory studies with bacterial cultures (e.g., Granger et al., 2008) have demonstrated that fractionation during denitrification causes that $\delta^{15} \mathrm{~N}_{\mathrm{NO} 3}$ and $\delta^{18} \mathrm{O}_{\mathrm{NO} 3}$ become progressively more enriched as $\mathrm{NO}_{3}$ depletion proceeds. Fig. 1d shows a clear trend of $\delta^{15} \mathrm{~N}_{\mathrm{NO} 3}$ enrichment with time and correlate with the decreasing nitrate levels observed in Fig. 1a, suggesting strong evidence of
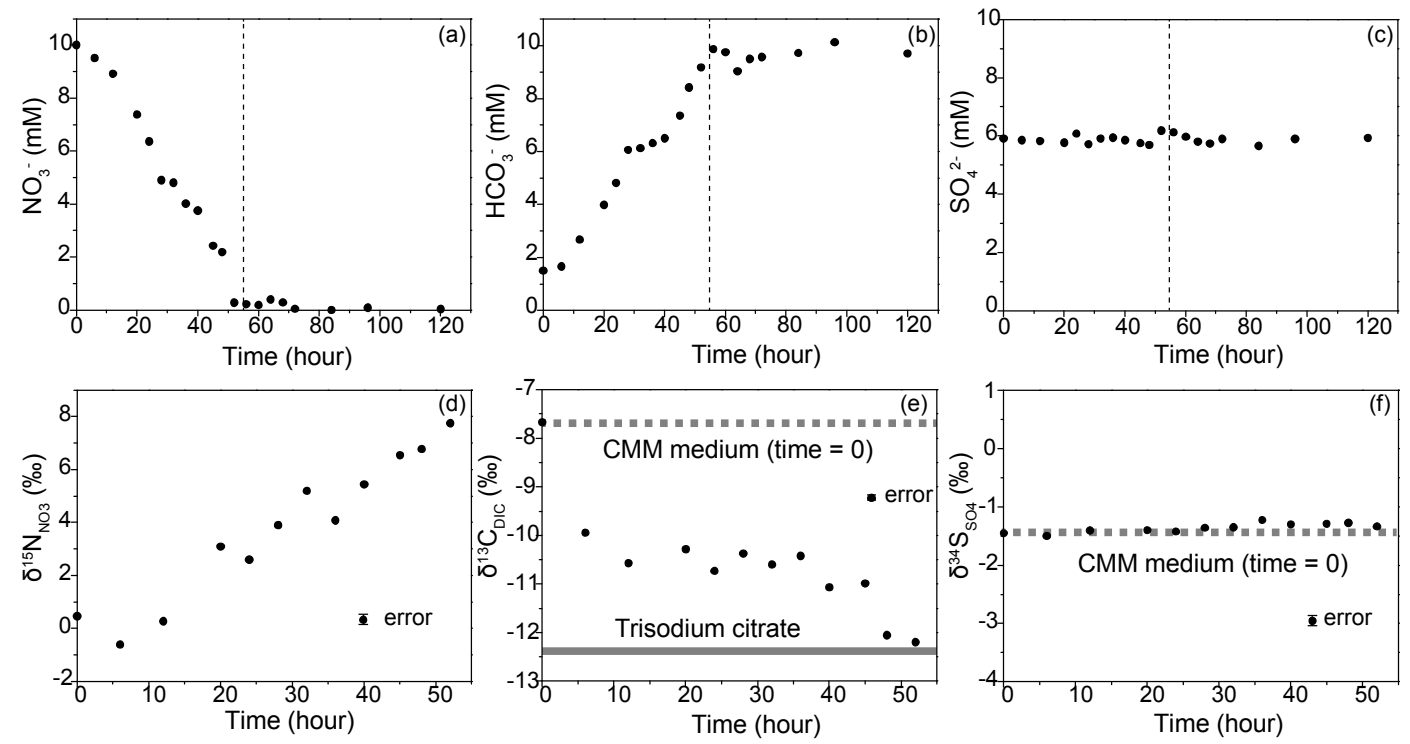

Fig. 1 Time depending change of concentration and isotope ratios during heterotrophic denitrification: (a) Nitrate, (b) bicarbonate, (c) sulfate, (d) $\delta^{15} \mathrm{~N}_{\mathrm{NO} O}$, (e) $\delta^{13} \mathrm{C}_{\mathrm{DIC}}$, and (f) $\delta^{34} \mathrm{~S}_{\mathrm{SO} 4}$. The solid and dotted lines represent the measured isotope values for the trisodium citrate and CMM medium, respectively. 
denitrification. In this experiment $\delta^{18} \mathrm{O}_{\mathrm{NO} 3}$ could not be measured accurately; however, the behavior of $\delta^{18} \mathrm{O}_{\mathrm{NO} 3}$ is out of scope of this study. Fig. 1e shows that as citrate is being consumed $\delta^{13} \mathrm{C}_{\mathrm{DIC}}$ tend to approximate to its value (Table 2). No fractionation occurred for $\delta^{34} \mathrm{~S}_{\mathrm{SO} 4}$ as can be observed in Fig. $1 \mathrm{f}$.

Fig. 2a shows the nitrate concentration variation with time for the AD reaction. Nitrate concentration decreased from approximately $5 \mathrm{mM}$ to $2 \mathrm{mM}$ in 70 days that was the duration of the experiment. The degree of denitrification reached $60 \%$, much lower than the one achieved with HD. Autotrophic microorganisms are relatively slow growing as compared to heterotrophs (Komor and Fox, 2002) resulting in small growth during the experiment. In the $\mathrm{AD}$ experiment, for every time point steep changes in the $\mathrm{NO}_{3}{ }^{-}, \mathrm{HCO}_{3}{ }^{-}$and $\mathrm{SO}_{4}{ }^{2-}$ concentrations occurred during the first thirteen days of the experiment (Figs. 2a to 2c). The $\mathrm{pH}$ of the cell culture medium (which contained $\mathrm{HCO}_{3}{ }^{-}$) was adjusted to be near 7-7.5; therefore, DIC can be expected to be only in the predominant form of $\mathrm{HCO}_{3}{ }^{-}$. All autotrophic bacteria utilize DIC concentrations in their host environment as carbon source to support various physiological functions involving DIC (Kusian et al., 2002). In other words, $\mathrm{CO}_{2}$ can be used a sole source of carbon for growth. Due to this fact, the concentration of $\mathrm{CO}_{2}$ expressed as $\mathrm{HCO}_{3}{ }^{-}$decreased with time as the experiment proceeded (Fig. 2b). According to our results, the molar ratio of
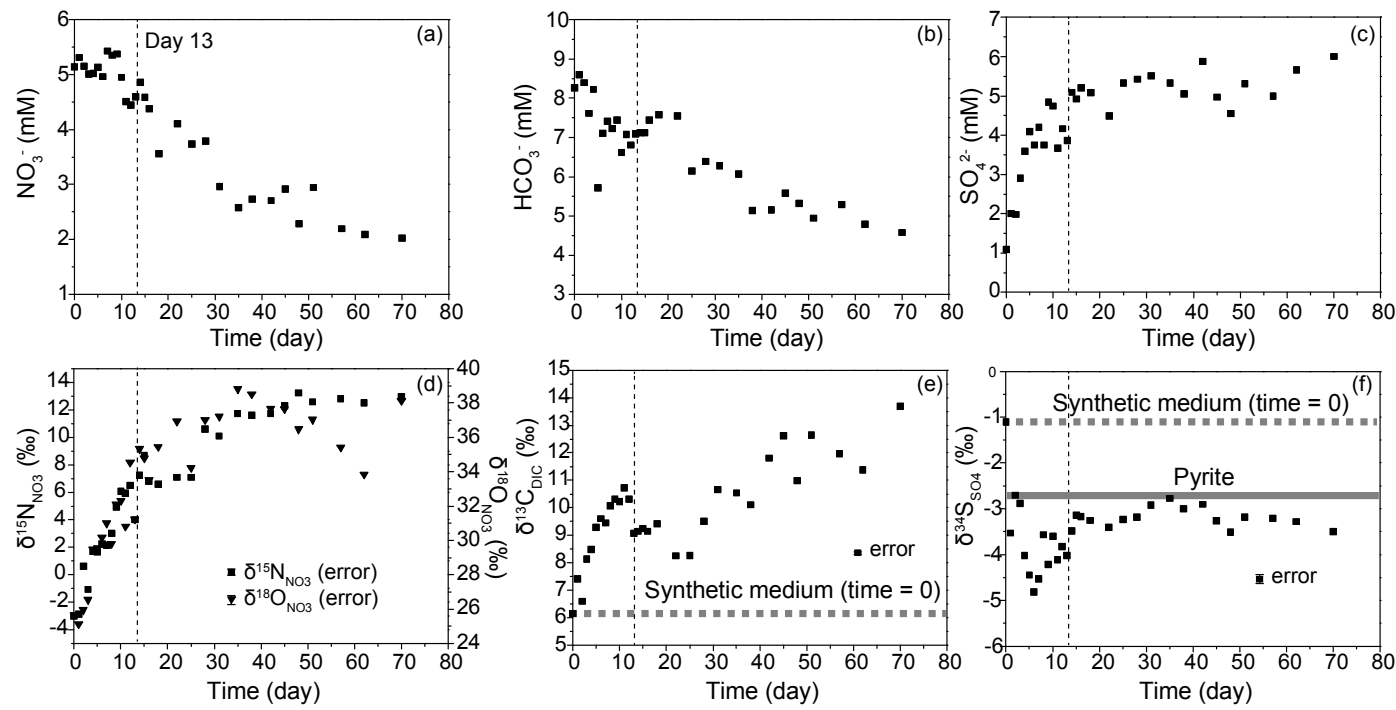

Fig. 2 Time depending change of concentration and isotope ratios during autotrophic denitrification: (a) Nitrate, (b) bicarbonate, (c) sulfate, (d) $\delta^{15} \mathrm{~N}_{\mathrm{NO} 3}$ and $\delta^{18} \mathrm{O}_{\mathrm{NO} 3}$, (e) $\delta^{13} \mathrm{C}_{\mathrm{DIC}}$, and (f) $\delta^{34} \mathrm{~S}_{\mathrm{SO} 4}$. The solid and dotted lines represent the measured isotope values for the pyrite and synthetic medium, respectively.

the reactants $\mathrm{NO}_{3}{ }^{-}$and produced $\mathrm{HCO}_{3}{ }^{-}$seems to be approximately $1: 1$.

Sulfate concentration increased with time as denitrification continues due to the 
oxidation of pyrite forming sulfate (Fig. 2c). However, we observed that the amount of $\mathrm{SO}_{4}{ }^{2-}$ formed is more than the expected stoichiometrically according to reaction (2). In our experimental conditions, we made an effort to avoid the chemical oxidation of pyrite; however, at the very beginning of the experiment during the equilibration time in the glove box, pyrite may be oxidized by dissolved molecular oxygen according to the following reaction (Singer and Stumm, 1970):

$\mathrm{FeS}_{2}+3.5 \mathrm{O}_{2}+\mathrm{H}_{2} \mathrm{O} \rightarrow \mathrm{Fe}^{2+}+\mathrm{SO}_{4}{ }^{2-}+2 \mathrm{H}^{+}$

Reaction (7) is a general reaction because other sulfur species, such as elemental sulfur, could also form as oxidation products (Schippers et al., 1996). Field studies clearly demonstrate pyrite oxidation in neutral and slightly alkaline groundwater (e.g., Postma et al., 1991; Kinniburg et al., 1994; Schreiber et al., 2000). Microbial examination of groundwater in a zone with ongoing pyrite oxidation suggests that the oxidation is abiotic (Kinniburg et al., 1994). The rate of reaction (7) is limited by the availability of dissolved oxygen, which may come from either atmospheric oxygen, water-derived oxygen and/or adsorbed molecular oxygen onto the pyrite surface, especially on ultrafine pyrite grains (Heidel and Tichomirowa, 2011). During the first thirteen days of the experiment the $\mathrm{SO}_{4}{ }^{2-}$ generation can be simultaneously attributed to Eq. (2) and Eq. (7), taking into account that in waters with high nitrate concentrations $T$. denitrificans microbially catalyze reaction (2) (Welch et al., 2000). Nevertheless, little is known about the kinetics, mechanisms, the limiting factors and the degree of involvement of T. denitrificans like bacteria in reaction (2) (Torrentó et al., 2010). From 14 days on, the sulfate production was less steeply as the time increases and this behavior could be attributed to the decrease of the bacterial activity, which should catalyze reaction (2).

On Figs. $2 \mathrm{~d}-\mathrm{f} \delta^{15} \mathrm{~N}_{\mathrm{NO} 3}$ and $\delta^{18} \mathrm{O}_{\mathrm{NO} 3}, \delta^{13} \mathrm{C}_{\mathrm{DIC}}$, and $\delta^{34} \mathrm{~S}_{\mathrm{SO} 4}$ are plotted vs. time. As a clear evidence of denitrification, it was seen that the isotopic fractionation of nitrogen and oxygen increased with time, especially during the first thirteen days of the experiment (Fig. 2d), which is coincident with the concentration changes observed in Figs. 2a-c. AD resulted in a decrease in $\mathrm{HCO}_{3}{ }^{-}$concentration together with an increase in $\delta^{13} \mathrm{C}_{\text {DIC. }}$. In Fig. 2e during the first 13 days and after the day 25 fractionation of $\delta^{13} \mathrm{C}_{\mathrm{DIC}}$ can be observed, meaning that the T. denitrificans bacteria prefer to uptake the light isotope ${ }^{12} \mathrm{C}$ leaving the remaining carbon progressively enriched in ${ }^{13} \mathrm{C}$. The $\delta^{13} \mathrm{C}_{\mathrm{DIC}}$ for $\mathrm{AD}$ range from $6.1 \%$, that is the DIC present in the synthetic medium (Table $2, n=5)$, to $13.7 \%$. We still don't have clear evidence to explain why less fractionated 
signature in $\delta^{13} \mathrm{C}_{\mathrm{DIC}}$ with high $\mathrm{HCO}_{3}{ }^{-}$concentration was observed during days 13 and 25 (Fig. 2e). Since the $\mathrm{pH}$ was maintained stable during all the experiment, we can infer that bacterial physiological changes and/or variation in the denitrifying bacterial activity during this period may be occurred producing this phenomenon. Since in our batch system the bacterial are continuously growing, the microbial activity is somehow variable.

In Fig. $2 f$, in the first time point, the sulfate concentration was sufficiently high to recover a measurable quantity of barium sulfate (day 0 ) and yielded a $\delta^{34} \mathrm{~S}_{\mathrm{SO} 4}$ value of $-1.1 \%$. It is possible that in the initial superficial preparation of $\mathrm{FeS}_{2}$ crystal a certain amount of S impurities remained. Lasaga (1998) has reported S release probably due to the dissolution of an outer layer of the reacting material or to dissolution of microparticles. Moreover, S-rich secondary phases or elemental S as an intermediate phase could have been formed at the beginning of the experiment, as suggested by Torrentó et al. (2010). The possible subsequent oxidation of this $\mathrm{S}^{0}$ product cannot be discarded also. Therefore, the $\delta^{34} \mathrm{~S}_{\mathrm{SO} 4}$ value obtained at day 0 could be the sum of these factors. In correspondence with the increasing tendency of sulfate concentration, $\delta^{34} \mathrm{~S}$ decreased from $-1.1 \%$ o toward the value of pyrite $(-2.7 \%$ ), strongly suggesting the occurrence of pyrite oxidation through AD reaction. Significant decline of $\delta^{34} \mathrm{~S}_{\mathrm{SO} 4}$ was observed (-4.8\% in maximum) during first 13 days and after 14 days this trend gradually weaken (Fig. 2f). This tendency corresponds well with $\mathrm{SO}_{4}{ }^{2-}$ concentration changing behavior (Fig. 2c) as described previously.

\subsection{Evaluation of enrichments factors}

Using equations 3-5, we calculated the enrichment factors for $\mathrm{HD}$ and $\mathrm{AD}$. For the HD experiment, the enrichment factor calculated by the linear regression line of $\delta^{15} \mathrm{~N}_{\mathrm{NO} 3}$ vs. $\ln \left[\mathrm{NO}_{3}{ }^{-}\right]$is shown in Fig. 3a. The value of $\varepsilon \mathrm{N}$ based on the slope of the regression line was $-4.7 \%$. Granger et al. (2008) measured $\varepsilon \mathrm{N}$ in heterotrophic cultures of different denitrifying bacteria and the obtained values spanned a broad range, between $-5 \%$ and -25\% . Sutka et al. (2006) measured $\varepsilon \mathrm{N}$ in a batch experiment using $P$. aerofaciens, citrate electron donor and $0.01 \mathrm{mM} \mathrm{NaNO}_{3}$ (conditions very similar to our experimental conditions except for the cell concentration and the initial concentration of $\mathrm{NO}_{3}$ ) and the $\varepsilon \mathrm{N}$ obtained was $-36.7 \%$. Enrichment factors in the range of $-5 \%$ o to $-10 \%$ o indicate rapid denitrification reactions (Mariotti et al., 1988). The regression coefficient of the plot of Fig. 3(a) was $r^{2}=0.82$. As was mentioned before, a lack of perfect linearity can be due to a variety of microscale biological transport processes and other physical 
processes that are involved in the microbial denitrification.
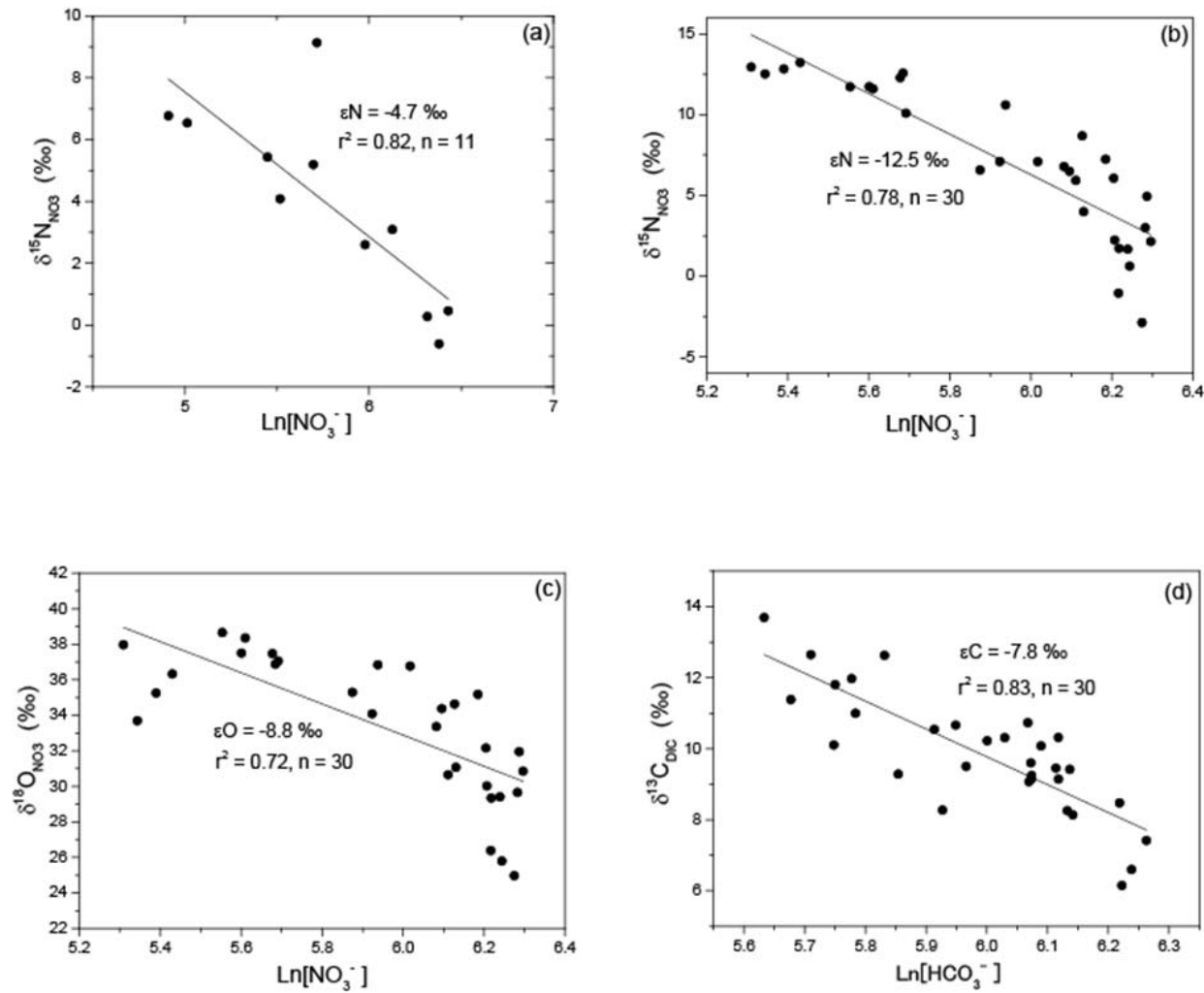

Fig. 3 (a) $\delta^{15} \mathrm{~N}_{\mathrm{NO} 3}$ vs. $\ln \left[\mathrm{NO}_{3}^{-}\right]$during heterotrophic denitrification (the last point corresponding to the $\mathrm{NO}_{3}$ concentration of almost $0 \mathrm{mM}$ was excluded in the regression analysis), (b) $\delta^{15} \mathrm{~N}_{\mathrm{NO} 3}$ vs. $\ln \left[\mathrm{NO}_{3}{ }^{-}\right]$during autotrophic denitrification, (c) $\delta^{18} \mathrm{O}_{\mathrm{NO} 3}$ vs. $\ln \left[\mathrm{NO}_{3}{ }^{-}\right]$ during autotrophic denitrification, and (d) $\delta^{13} \mathrm{C}_{\mathrm{DIC}}$ vs. $\ln \left[\mathrm{HCO}_{3}^{-}\right]$during autotrophic denitrification.

Figs. $3 b, c$ showed the correlation between $\delta^{15} \mathrm{~N}_{\mathrm{NO} 3}$ vs. $\ln \left[\mathrm{NO}_{3}{ }^{-}\right]$and $\delta^{18} \mathrm{O}_{\mathrm{NO} 3}$ vs. $\ln \left[\mathrm{NO}_{3}{ }^{-}\right]$for the $\mathrm{AD}$ experiment. The initial $\left[\mathrm{NO}_{3}{ }^{-}\right]$was around $5 \mathrm{mM}$ and we found enrichment factors of $\varepsilon \mathrm{N}=-12.6 \%$ and $\varepsilon \mathrm{O}=-8.8 \%$, respectively. Although, the achievement of denitrification in our $\mathrm{AD}$ experiment was $60 \%$, the enrichment factors calculated using the data of Figs. 3b,c resulted to be similar to the ones reported by Torrentó et al. (2010) $(\varepsilon \mathrm{N}=-15.01 \%$ and $\varepsilon \mathrm{O}=-13.55 \%$, which until date is the only study that measured $\varepsilon \mathrm{N}$ and $\varepsilon \mathrm{O}$ in an autotrophic denitrification experiment using pyrite as an electron donor.

Fig. $3 \mathrm{~d}$ depicts the enrichment factors of carbon during $\mathrm{AD}$ reaction. The obtained value for $\varepsilon \mathrm{C}$ was $-7.8 \%$. The $\varepsilon \mathrm{S}$ could not be calculated since a linear relationship between $\delta^{34} \mathrm{~S}$ and $\ln \left[\mathrm{SO}_{4}\right]$ was not obtained; however, significant sulfur isotope 
fractionation was observed during the first thirteen days of the experiment, decreasing down to $-4.8 \%$ in maximum (Fig. $2 \mathrm{f}$ ), which value is around $2 \%$ o lower than that of pyrite $(-2.7 \%)$. This negative shift of $\delta^{34} \mathrm{~S}$ value should account for the occurrence of pyrite oxidation through Eqs. (2) and (7) simultaneously. Observed degree of fractionation corresponds well with the values reported in the sulfide oxidation by $\mathrm{O}_{2}$ (coming from atmospheric oxygen) or water molecule oxygen $\left(\mathrm{O}\right.$ in $\left.\mathrm{H}_{2} \mathrm{O}\right)$ (Balci et al., 2007).

Denitrification reaction can produce a distinctive isotope signature on a cross-plot of $\delta^{15} \mathrm{~N}_{\mathrm{NO} 3}$ vs. $\delta^{18} \mathrm{O}_{\mathrm{NO} 3}$. For $\mathrm{AD}$, values of $\delta^{15} \mathrm{~N}_{\mathrm{NO} 3}$ and $\delta^{18} \mathrm{O}_{\mathrm{NO} 3}$ tended to be linearly correlated (Fig. 4). A best-fit regression line allowed determining the ratio of isotopic enrichment factor $\varepsilon \mathrm{N} / \varepsilon \mathrm{O}$. The slope of the line indicates that $\delta^{15} \mathrm{~N}$ fractionates by a factor of 1.04 greater than $\delta^{18} \mathrm{O}$. For the HD experiment, the $\varepsilon N / \varepsilon O$ ratio could not be calculated, however, for the AD experiment, the isotopic enrichment factor $\varepsilon \mathrm{N} / \varepsilon \mathrm{O}$ ratio resulted to be in agreement with the ratio obtained by Torrentó et al. (2010), which is a same study of $\mathrm{AD}$ using pyrite (with a different grain size, which is bigger than the one

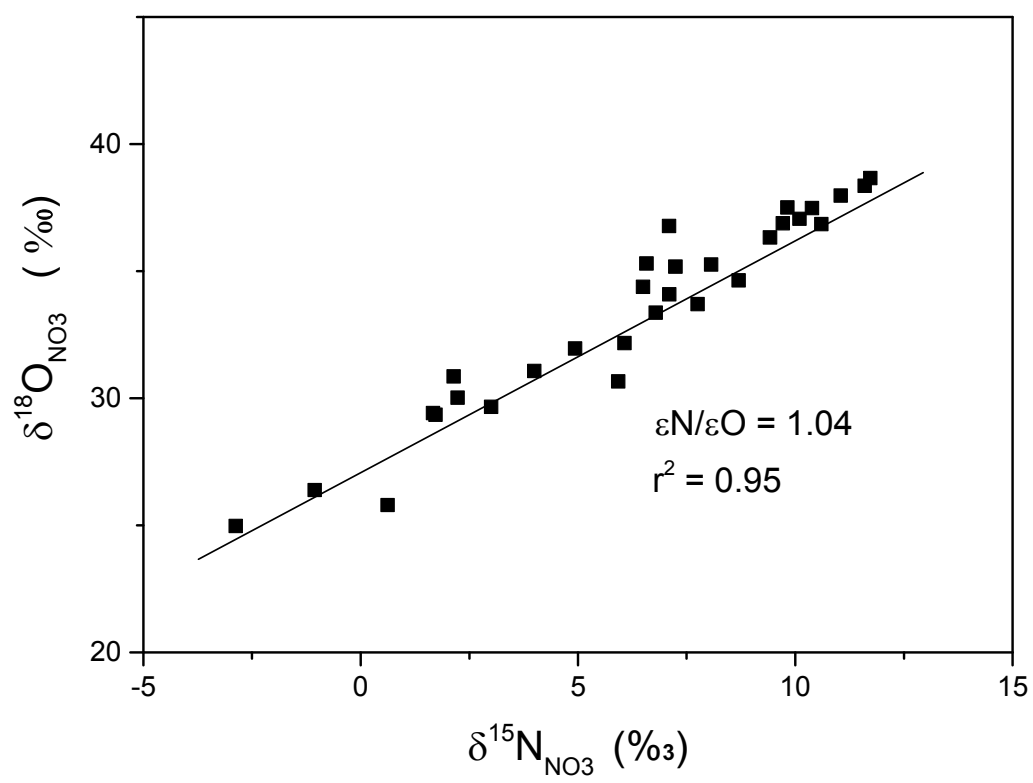

Fig. 4 Isotopic signatures $\left(\delta^{18} \mathrm{O}_{\mathrm{NO} 3}\right.$ vs. $\left.\delta^{15} \mathrm{~N}_{\mathrm{NO} 3}\right)$ during autotrophic denitrification used in our experiment) and Thiobacillus denitrificans $(\varepsilon \mathrm{N} / \varepsilon \mathrm{O}=1.13-1.18)$. These values are also comparable to the ratios obtained from field studies of denitrification in groundwater in natural environments (Otero et al., 2009). 


\subsection{Potential applications in the groundwater environmental studies}

The different comportments for HD and AD presented in $\delta^{15} \mathrm{~N}_{\mathrm{NO} 3}$ vs. $\delta^{13} \mathrm{C}_{\text {DIC }}$ and $\delta^{15} \mathrm{~N}_{\mathrm{NO} 3}$ vs. $\delta^{34} \mathrm{~S}_{\mathrm{SO} 4}$ diagrams are very important, because, comparing across the multi-isotope behavior allow us ideally to assess the type of denitrification that is taking place in subsurface environments (Aravena and Robertson, 1998; Otero et al., 2009; Carrey et al., 2013; Puig et al., 2013; Hosono et al., 2014). Figs. 5a,b displays the relationship between $\delta^{15} \mathrm{~N}_{\mathrm{NO} 3}$ and $\delta^{13} \mathrm{C}_{\mathrm{DIC}}$ and $\delta^{15} \mathrm{~N}_{\mathrm{NO} 3}$ and $\delta^{34} \mathrm{~S}_{\mathrm{SO} 4}$, respectively, for HD and $\mathrm{AD}$. For HD, as nitrate is being consumed a decrease of $\delta^{13} \mathrm{C}_{\mathrm{DIC}}$ was observed to the value of the trisodium citrate $(-12.4 \%$ ), while denitrification is taking place no fractionation of $\delta^{34} \mathrm{~S}_{\mathrm{SO} 4}$, was observed (Fig. 5b). The variation of $\delta^{13} \mathrm{C}_{\mathrm{DIC}}$ and $\delta^{34} \mathrm{~S}_{\mathrm{SO} 4}$ with $\delta^{15} \mathrm{~N}_{\mathrm{NO} 3}$ for HD was in agreement with the obtained by the scenario suggested by Aravena and Robertson (1998).

In contrast, for $\mathrm{AD}$, as denitrification proceeded, clear isotopic fractionation of $\delta^{13} \mathrm{C}_{\mathrm{DIC}}$ (from 6 to $14 \%$ ) with $\varepsilon \mathrm{C}$ of $-7.8 \%$ and an enrichment factor ratio $\varepsilon \mathrm{N} / \varepsilon \mathrm{C}$ of 0.3
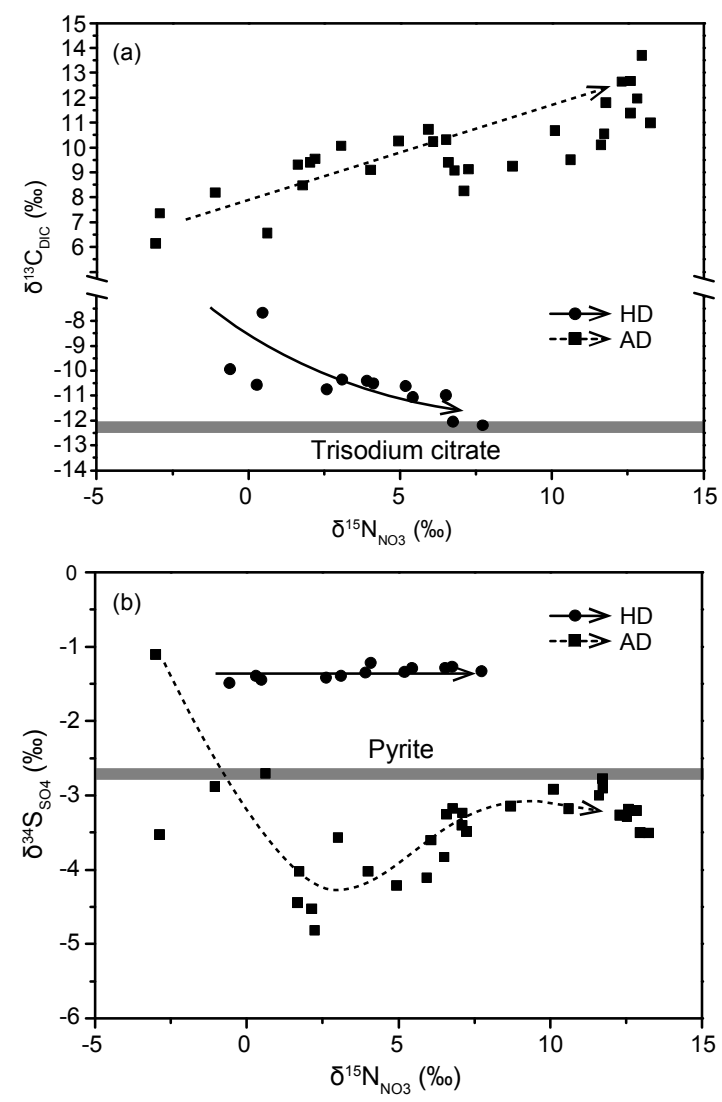

Fig. 5 Isotopic comparison between heterotrophic and autotrophic denitrification on (a) $\delta^{13} \mathrm{C}_{\text {DIC }}$ vs. $\delta^{15} \mathrm{~N}_{\mathrm{NO} 3}$ and (b) $\delta^{34} \mathrm{~S}_{\mathrm{SO} 4}$ vs. $\delta^{15} \mathrm{~N}_{\mathrm{NO} 3}$ diagram. 
were observed. In addition, $\delta^{34} \mathrm{~S}_{\mathrm{SO} 4}$ decreased with the progress of denitrification reaction and shifts towards more negative values than $\delta^{34} \mathrm{~S}_{\mathrm{SO} 4}$ of the pyrite. In other words, a slight but clear $\delta^{34} \mathrm{~S}$ fractionation (around -2\%o in maximum) during AD reaction in addition to low $\delta^{34} \mathrm{~S}$ signature of pyrite $(-2.7 \%$ ) was observed. In natural nitrate-rich aquifers, zones with imperfectly anaerobic conditions are present (suboxic environment) and under this conditions the simultaneous occurrence of reaction (7) and (8) could be present. Otero et al. (2009) found a decrease in $\delta^{34} \mathrm{~S}_{\mathrm{SO} 4}$ accompanied by an enrichment of $\delta^{15} \mathrm{~N}_{\mathrm{NO} 3}$. Their results are partially similar to those of our results; however, in this study we found a fractionation of approximately $-2 \%$ for $\delta^{34} \mathrm{~S}_{\mathrm{SO} 4}$ and an increase in $\delta^{13} \mathrm{C}_{\text {DIC }}$ with the increase of $\delta^{15} \mathrm{~N}_{\mathrm{NO} 3}$.

In the field, dissolved species of organic and inorganic carbon take part in microbial reactions and alter the $\delta^{13} \mathrm{C}_{\text {DIC }}$ value. In fact, in the aquifer systems including carbonate units, Otero et al. (2009) could not detect a clear trend between carbon concentration and $\delta^{13} \mathrm{C}_{\text {DIC }}$ during AD. However, we suppose that in different types of aquifers, such as shale aquifer with defined pyrite zone where significant occurrence of $\mathrm{AD}$ has been confirmed (Molénat and Gascuel-Odoux, 2002), the carbon isotopic signature might be a sensitive indicator of $\mathrm{AD}$ process with combination use of $\delta^{34} \mathrm{~S}_{\mathrm{SO} 4}$ tracer. Detailed behavior of $\delta^{13} \mathrm{C}_{\mathrm{DIC}}$ and $\delta^{34} \mathrm{~S}_{\mathrm{SO} 4}$ versus $\delta^{15} \mathrm{~N}_{\mathrm{NO} 3}$ found in our batch culture experimental study (Fig. 5) would be helpful to understand which type of denitrification is occurring in particular aquifer systems of natural environments.

\section{Concluding remarks}

The results of our batch experimental study demonstrated the usefulness of N-C-S isotopic combination to understand the type of anaerobic bacterial denitrification processes (autotrophic or heterotrophic) in contaminated groundwater where a carbon source and/or pyrite are present. However, in natural aquifers, mixing with another $\mathrm{S}$ and $\mathrm{C}$ sources such through dissolution of carbonate materials and marine evaporites, and other anaerobic microbial activities such as sulfate reduction and methanogenesis would take place after or in the middle of the progress of the denitrification reaction, which play a decisive role changing isotope ratios of carbon and sulfur (Hosono et al., 2014). Nevertheless, obtained results can be applicable in environments where complex simultaneous anaerobic reactions would not occur after, in the middle of the denitrification reaction, or at organic poor land that prevent further heterotrophic bacterial reactions to proceed. Although this is a batch experiment study, our results using could be qualitatively applied to natural environments to better understand HD 
and pyrite-driven $\mathrm{AD}$ in aquifers.

\section{Acknowledgement}

This study was funded by a Grant-in-Aid for Young Scientist (A) (No. 24681007) and by the CREST Project (JST: Japan Science and Technology Agency).

\section{References}

Akunna JC, Bizeau, C, Moletta, R (1993) Nitrate and nitrite reductions with anaerobic sludge using various carbon sources: Glucose, glycerol, acetic acid, lactic acid and methanol. Water Res. 27:1303-1312

Anderson IC, Poth M., Homstead J, Burdige DA (1993) Comparison of NO and $\mathrm{N}_{2} \mathrm{O}$ production by the autotrophic nitrifier Nitrosomonas europaea and the heterotrophic nitrifier Alcaligenes faecalis. Appl. Environ. Microbio. 59:3525-3533

Aravena R, Robertson WD (1998) Use of multiple isotope tracers to evaluate denitrification in ground water: study of nitrate from a large-flux septic system plume. Ground Water 36:975-982

Aslan S, Turkman A (2005) Combined biological removal of nitrate and pesticides using wheat straw as substrates. Process Biochem. 40:935-943

Balci N, Shanks III WC, Mayer B, Mandernack KW (2007) Oxygen and sulfur isotopes systematics of sulfate produced by bacterial and abiotic oxidation of pyrite. Geochim. Cosmochim. Acta 71:3796-3811

Barford CC, Montoya JP, Altabet MA, Mitchell R (1999) Steady-state nitrogen isotope effects of $\mathrm{N}_{2}$ and $\mathrm{N}_{2} \mathrm{O}$ production in Paracocus denitrificans. Appl. Environ. Microbiol. 65:989-994

Batchelor B, Lawrence AW (1986) Autotrophic denitrification using elemental sulfur. J. Water Poll. Control Fed. 50:1986-2001

Benz M, Brune A, Schink B (1998) Anaerobic and aerobic oxidation of ferrous iron at neutral $\mathrm{pH}$ by chemoheterotrophic nitrate-reducing bacteria. Arch. Microbiol. 169:159-165

Biswas S, Bose P (2005) Zero-valent iron-assisted autotrophic denitrification. J. Environ. Eng. 131:1212-1220

Bottrell SH, Newton RJ (2006) Reconstruction of changes in global sulfur cycling from marine sulfate isotopes. Earth-Science Rev. 75:59-83

Böttcher J, Strebel O, Voerkelius S, Schmidt H-L (1990) Using isotope fractionation of nitrate-nitrogen and nitrate-oxygen for evaluation of microbial denitrification in sandy aquifer. J. Hydrol. 114: 413-424 
Brabec MY, Lyons TW, Mandernack KW (2012) Oxygen and sulfur isotope fractionation during sulfide oxidation by anoxygenic phototrophic bacteria. Geochim. Cosmochim. Acta 83: 234-251

Button DK (1991) Biochemical basis for whole-cell uptake kinetics:specific affinity, oligotrophic capacity, and the meaning of the Michaelis constant. Appl. Environ. Microbiol. 57:2033-2038

Button DK (1998) Nutrient uptake by microorganism according to kinetic parameters from theory as related to cytoarchitecture. Microbiol. Mol. Biol. Rev. 62:636-645

Carrey R, Otero N, Soler A, Gómez-Alday JJ, Ayora C (2013) The role of Lower Cretaceous sediments in groundwater nitrate attenuation in central Spain: Column experiments. Appl. Geochem. 32:142-152

Casciotti KL, Sigman DM, Hastings MG, Bohlke JK, Hilkert A (2002) Measurement of the oxygen isotopic composition of nitrate in seawater and freshwater using the denitrifier method. Anal. Chem. 74:4905-4912

Choe SH, Ljestrand HM, Khim J (2004) Nitrate reduction by zero-valent iron under different pH regimes. Appl. Geochem. 19:335-342

Christensson M, Lie E, Welander TA (1994) Comparison between ethanol and methanol as carbon sources for denitrification. Water Sci. Technol. 30:83-90

Delwiche CC, Steyn PL (1970) Nitrogen isotope fractionation in soils and microbial reactions. Environ. Sci. Technol. 4:929-935

Fukada T, Hiscock KM, Dennis PF, Grischeck T (2003) A dual isotope approach to identify denitrification in groundwater at a river-bank infiltration site. Water Res. 37:3070-3078

Granger J, Sigman DM, Lehmann MF, Tortell PD (2008) Nitrogen and oxygen isotope fractionation during dissimilatory nitrate reduction by denitrifying bacteria. Limnol. Oceanogr. 53:2533-2545

Haaijer SCM, Lamers LPM, Smolders AJP, Jetten MSM, Op de Camp HJM (2007) Iron sulfide and pyrite as potential electron donors for microbial nitrate reduction in freshwater wetlands. Geomicrobiol. J. 24:391-401

Harms H (1996) Bacterial growth on distant naphthalene diffusing through water, air, and water-saturated and nonsaturated porous media. Appl. Environ. Microbiol. 62: 2286-2293

Heidel C, Tichomirowa M (2011) The isotopic composition of sulfate from anaerobic and low oxygen pyrite oxidation experiments with ferric iron-New insights into oxidation mechanisms. Chem. Geol. 281:305-316

Heidel C, Tichomirowa M, Junghans M (2013) Oxygen and sulfur isotope 
investigations of the oxidation of sulfide mixtures containing pyrite, galena, and sphalerite. Chem. Geol. 342:29-43

Hosono T, Tokunaga T, Tsushima A, Shimada J (2014) Combined use of $\delta 13 \mathrm{C}, \delta 15 \mathrm{~N}$, and $\delta 34 \mathrm{~S}$ tracers to study anaerobic bacterial processes in groundwater flow systems. Water Res. 54:284-296

Jorgensen CJ, Jacobsen OS, Elberling B, Aamand J (2009) Microbial oxidation of pyrite coupled to nitrate reduction in anoxic groundwater sediment. Environ. Sci. Technol. 43:4851-4857

Kinniburg DG, Gale IN, Smedley PL, Darling WG, West JM, Kimblin RT, Parker A, Rae JE, Aldous PJ, O'Shea MJ (1994) The effects of historic abstraction of groundwater from the London Basin aquifers on groundwater quality. Appl. Geochem. 9:175-196

Krouse HR, Grinenko VA (1991) Stable isotopes: natural and anthropogenic sulphur in the environment. Scientific Committee on Problems of the Environment (SCOPE) 43, John Wiley \& Sons. 464 pp.

Knöller K, Vogt C, Haupt M, Feisthauer S, Richnow H-H (2011) Experimental investigation of nitrogen and oxygen isotope fractionation in nitrate and nitrite during denitrification. Biogeochem. 103:371-384

Komor A, Fox P (2002) Evaluation of denitrification rates and mechanisms in microcosm experiments with sediments and plants. In: Water Environment Federation (eds) Proceedings of the Water Environment Federation, WEFTEC 2002, Chicago, IL, USA, pp 496-514

Korom SF (1992) Natural denitrification in the unsaturated zone: a review. Water Resour. Res. 28:1657-1668

Kusian B, Sültemeyer D, Bowien, B (2002) Carbonic anhydrase is essential for growth of Ralstonia eutropha at ambien $\mathrm{CO}_{2}$ concentrations. J. Bacteriology 184:5018-5026

Lasaga AC (1998) Kinetic Theory in the Earth Sciences. Princenton University Press: Princenton, New Jersey, USA, p 728

Lewicka-Szczebak D, Well R, Köster JR, Fuß R, Senbayram M, Dittert K, Flessa H (2014) Experimental determinations of isotopic fractionation factors associated with $\mathrm{N}_{2} \mathrm{O}$ production and reduction during denitrification in soils. Geochim. Cosmochim. Acta 134:55-73

Mariotti A, Germon JC, Hubert P, Kaiser P, Letolle R, Tardieux A, Tardieux, P (1981) Experimental determination of nitrogen kinetic isotope fractionation: Some principles; Illustration for the denitrification and nitrification processes. Plant Soil 
62:413-430

Mariotti A, Landreau A, Simon B (1988) ${ }^{15} \mathrm{~N}$ isotope biogeochemistry and natural denitrification process in groundwater: Application to the chalk aquifer of northern France. Geochim. Cosmochim. Acta 52:1869-1878

Meckenstock RU, Morasch B, Griebler C, Richnow HH (2004) Stable isotope fraction analysis as a tool to monitor biodegradation in contaminated aquifers. J. Contam. Hydrol. 75:215-255

Mengis M, Schif SL, Harris M, English MC, Aravena R, Elgood RJ, MacLean A (1999) Multiple geochemical and isotopic approaches for assessing ground water $\mathrm{NO}_{3}$ elimination in a riparian zone. Ground Water 37:448-457

Mohammadi AS, Movahedian, H, Nikaeen M (2011) Drinking water denitrification with autotrophic denitrifying bacteria in a fluidized bed bioreactor (FBBR). Fresenius Environ. Bull. 20:2427-2434

Molénat J, Gascuel-Odoux C (2002) Modelling flow and nitrate transport in groundwater for the prediction of water travel times and of consequences of land use evolution on water quality. Hydrol. Process. 16:479-492

Nascimento C, Atekwana E A, Krishnamurthy R V (1997) Concentrations and isotope ratios of dissolved inorganic carbon in denitrifying environments. Geophys. Res. Letters 24:1511-1514

Nyberg U, Andersson, B, Aspegren, H (1996) Long-term experiences with external carbon sources for nitrogen removal. Water Sci. Technol. 33:109-116

Otero N, Torrentó C, Soler A, Menció A, Mas-Pla J (2009) Monitoring groundwater nitrate attenuation in a regional system coupling hydrogeology with multi-isotopic methods: The case of Plana de Vic (Osona, Spain). Agric. Ecosyst. Environ. 133:103-113

Pisapia C, Chaussidon M, Mustin C, Humbert B (2007) O and S isotopic composition of dissolved and attached oxidation products of pyrite by Acidithiobacillius ferrooxidans: comparison with abiotic oxidation. Geochim. Cosmochim. Acta $71: 2474-2490$

Postma D, Boesen C, Kristiansen H, Larsen F (1991) Nitrate reduction in an unconfined sandy aquifer: water chemistry, reduction processes, and geochemical modeling. Water Resour. Res. 27:2027-2045

Puig R., Folch A, Menció A, Soler A, Mas-Pla, J (2013) Multi-isotopic study $\left({ }^{15} \mathrm{~N},{ }^{34} \mathrm{~S}\right.$, ${ }^{18} \mathrm{O},{ }^{13} \mathrm{C}$ ) to identify processes affecting nitrate and sulfate in response to local and regional groundwater mixing in a large-scale flow system. Appl. Geochem. $32: 129-141$ 
Rickard D, Luther III GW (2007) Chemistry of Iron Sulfides. Chem. Rev. 107:514-562

Sasaki K, Tsunekawa M, Ohtsuka T, Konno H. (1995) Confirmation of a sulfur-rich layer on pyrite after oxidative dissolution by $\mathrm{Fe}(\mathrm{II} 1)$ ions around $\mathrm{pH}$ 2. Geochim. Cosmochim. Acta. 59:3155-3158

Schipper LA, Barkle GF, Hadfield JC, Vojvodic-Vukovic M, Burgess CP (2004) Hydraulic constraints on the performance of a groundwater denitrification wall for nitrate removal from shallow groundwater. J. Cont. Hydrol. 69:263-279

Schippers A, Jozsa P-G, Sand W (1996) Sulfur chemistry in bacterial leaching of pyrite. Appl. Env. Microbiol. 62:3424-3431

Schreiber ME, Simo JA, Freiberg PG (2000) Stratigraphic and geochemical controls on naturally occurring arsenic groundwater, eastern Wisconsin, USA. Hydrogeol. J. 8:161-176

Schulte P, van Geldern R, Freitag H, Karim A, Négrel P, Petelet-Giraud E, Probst A, Probst J-L, Telmer K, Veizer J,. Barth JAC (2011) Applications of stable water and carbon isotopes in watershed research: Weathering, carbon cycling, and water balances. Earth-Science Rev. 109:20-31

Sigman DM, Casciotti KL, Andreani M, Barford C, Galanter M, Bohlke JK (2001) A bacterial method for the nitrogen isotopic analysis of nitrate in sea water and freshwater. Anal. Chem. 73:4145-4153

Singer PC, Stumm W (1970) Acidic mine drainage: the rate-determining step. Science 167:1121-1123

Soares MIM (2000) Biological denitrification of ground water. Water, Air, Soil Poll. 123:183-193

Soares MIM (2002) Denitrification of groundwater with elemental sulfur. Water Res. $36: 1392-1395$

Sutka RL, Ostrom NE, Ostrom PH, Breznak JA, Gandhi H, Pitt AJ, Li F (2006) Distinguishing nitrous oxide production from nitrification and denitrification on the basis of isotopomer abundances. Appl. Environ. Microbiol. 72:638-644

Thullner M, Kampara M, Richnow HH, Harms H, Wick LY (2008) Impact of bioavailability restrictions on microbially induced stable isotope fractionation. 1 . Theoretical calculation. Environ. Sci. Technol. 42:6544-6551

Thurston RS, Mandernack KW, Shanks III WC (2010) Laboratory chalcopyrite oxidation by Acidithiobacillus ferrooxidans: Oxygen and sulfur isotope fractionation. Chem. Geol. 269:252-261

Torrentó C, Cama J, Urmeneta J, Otero N, Soler A (2010) Denitrification of groundwater with pyrite and Thiobacillus denitrificans. Chem. Geol. 278:80-91 
Volokita M, Belkin S, Abeliovich, A, Soares MIM (1996a) Biological denitrification of drinking water using newspaper. Water Res. 30:965-971

Volokita M, Abeliovich A, Soares MIM (1996b) Denitrification of groundwater using cotton as a energy source. Water Sci. Tech. 34:379-385

Welch AH, Westjohn DB, Helsel DR, Wanty RB (2000) Arsenic in groundwater of the United States- occurrence and geochemistry. Ground Water 38:589-604

Well R, Eschenbach W, Flessa H, von de Heide C, Weymann D (2012) Are dual isotope and isotopomer ratios of $\mathrm{N}_{2} \mathrm{O}$ useful indicators for $\mathrm{N}_{2} \mathrm{O}$ turnover during denitrification in nitrate-contaminated aquifers? Geochim. Cosmochim. Acta 90:265-282

Wellman RP, Cook FD, Krouse HR (1968) Nitrogen-15: microbiological alteration of abudance. Science 161:269-270

Wunderlich A, Meckenstock R, Einsiedl F (2012) Effect of different carbon substrates on nitrate stable isotope fractionation during microbial denitrification. Environ. Sci. Technol. 46:4861-4864 


\section{Figure legends}

Fig. 1 Time depending change of concentration and isotope ratios during heterotrophic denitrification: (a) Nitrate, (b) bicarbonate, (c) sulfate, (d) $\delta^{15} \mathrm{~N}_{\mathrm{NO} 3}$, (e) $\delta^{13} \mathrm{C}_{\mathrm{DIC}}$, and (f) $\delta^{34} \mathrm{~S}_{\mathrm{SO} 4}$. The solid and dotted lines represent the measured isotope values for the trisodium citrate and CMM medium, respectively.

Fig. 2 Time depending change of concentration and isotope ratios during autotrophic denitrification. (a) Nitrate, (b) bicarbonate, (c) sulfate, (d) $\delta^{15} \mathrm{~N}_{\mathrm{NO} 3}$ and $\delta^{18} \mathrm{O}_{\mathrm{NO} 3}$, (e) $\delta^{13} \mathrm{C}_{\mathrm{DIC}}$, and (f) $\delta^{34} \mathrm{~S}_{\mathrm{SO} 4}$. The solid and dotted lines represent the measured isotope values for the pyrite and synthetic medium, respectively.

Fig. 3 (a) $\delta^{15} \mathrm{~N}_{\mathrm{NO} 3}$ vs. $\ln \left[\mathrm{NO}_{3}{ }^{-}\right]$during heterotrophic denitrification (the last point corresponding to the $\mathrm{NO}_{3}$ concentration almost $0 \mathrm{mM}$ was excluded in the regression analysis), (b) $\delta^{15} \mathrm{~N}_{\mathrm{NO} 3}$ vs. $\ln \left[\mathrm{NO}_{3}{ }^{-}\right]$during autotrophic denitrification, (c) $\delta^{18} \mathrm{O}_{\mathrm{NO} 3}$ vs. $\ln \left[\mathrm{NO}_{3}{ }^{-}\right]$during autotrophic denitrification, and (d) $\delta^{13} \mathrm{C}_{\mathrm{DIC}}$ vs. $\ln \left[\mathrm{HCO}_{3}{ }^{-}\right]$during autotrophic denitrification.

Fig. 4 Isotopic signatures $\left(\delta^{18} \mathrm{O}_{\mathrm{NO} 3}\right.$ vs. $\left.\delta^{15} \mathrm{~N}_{\mathrm{NO} 3}\right)$ during autotrophic denitrification.

Fig. 5 Isotopic comparison between heterotrophic and autotrophic denitrification on (a) $\delta^{13} \mathrm{C}_{\mathrm{DIC}}$ vs. $\delta^{15} \mathrm{~N}_{\mathrm{NO} 3}$ and (b) $\delta^{34} \mathrm{~S}_{\mathrm{SO} 4}$ vs. $\delta^{15} \mathrm{~N}_{\mathrm{NO} 3}$ diagram. 
Table 1 Conditions varied for denitrifiers in the denitrification experiments

\begin{tabular}{lll}
\hline Conditions & P. aerofaciens & T. denitrificans \\
\hline Medium & $\mathrm{CMM}^{*}$ & Synthetic \\
Electron donor & $\mathrm{Na}_{3} \mathrm{C}_{6} \mathrm{H}_{5} \mathrm{O}_{7}$ & $\mathrm{FeS}_{2}$ \\
Initial $\mathrm{NO}_{3}{ }^{-}$concentration & $10 \mathrm{mM}$ & $5 \mathrm{mM}$ \\
$\begin{array}{l}\text { Duration of the } \\
\text { experiment }\end{array}$ & $120 \mathrm{~h}$ & 70 days \\
Sampling interval & Every $4 \mathrm{~h}$ & For days 1-16 every \\
& & day, days 17-49 every \\
& & 3 days, days 50-70 \\
& & every 7 days \\
Mechanical stirring & No & No \\
\hline
\end{tabular}

*See text for details

Table $2 \delta^{13} \mathrm{C}$ and $\delta^{34} \mathrm{~S}$ of the source materials used in the denitrification experiments.

\begin{tabular}{llcc}
\hline $\begin{array}{l}\text { Denitification } \\
\text { type }\end{array}$ & Source material & $\delta^{13} \mathrm{C}(\%)$ & $\delta^{34} \mathrm{~S}(\%)$ \\
\hline $\mathrm{HD}$ & $\mathrm{CMM}(\%) d i u m($ time $=0)$ & -7.7 & -1.5 \\
& $\mathrm{Na}_{3} \mathrm{C}_{6} \mathrm{H}_{5} \mathrm{O}_{7}$ (electron donor) & -12.4 & no data \\
$\mathrm{AD}$ & $\mathrm{Modified} \mathrm{synthetic} \mathrm{medium} \mathrm{(time}=0)^{*}$ & 6.1 & -1.1 \\
& Pyrite $\left(\mathrm{FeS}_{2}\right)$ (electron donor) & no data & -2.7 \\
\hline
\end{tabular}

Note: the results are the average values of 5 repeated measurements.

* At time $=0$ the modified synthetic medium contained $\mathrm{FeS}_{2}$ 